\title{
ENTREVISTA COM AMARA MOIRA
}

Naná DeLuca'

Caio Jade Puosso

\section{Resumo}

Entrevista realizada com a escritora Amara Moira, por e-mail, em 20 de setembro de 2019, em São Paulo.

Amara Moira é travesti, feminista, doutora em teoria e crítica literária pela Unicamp (com tese sobre o Ulysses, de James Joyce) e autora do livro autobiográfico E se eu fosse puta (Hoo editora, 2016). Além disso, ela é autora do capítulo Destino Amargo no livro Vidas Trans - A Coragem de Existir (Astral Cultural, 2017), teve seu monólogo em pajubá Neca antologiado em A Resistência dos Vaga-lumes (Nós, 2019), vem estudando as obras escritas por pessoas trans no Brasil, com foco nas autobiografias, e tem publicado ensaios de crítica literária feminista sobre o cânone nacional.

Revista Crioula: Amara, há algum tempo, você começou uma busca por obras literárias de pessoas que perturbam as normas de gênero/sexo da sociedade brasileira. Se não me engano, o livro mais antigo que localizou foi Memórias de Madame Satã, de 1972. Quais são os critérios que você utiliza para localizar essas obras, ou seja, o que te leva a classificar um livro no espectro de uma literatura trans?

Amara Moira: Nem toda obra que cataloguei nessa lista foi escrita por pessoas que se reivindicavam trans, mas de qualquer forma pode-se argumentar que nenhuma dessas pessoas era indubitavelmente cis. Em A queda para o alto (1982), por exemplo, autobiografia de Anderson Herzer, um dos primeiros títulos a que tive acesso, em momento algum vemos o autor dizer-se "trans" ou mesmo "homem", mas é impossível não perceber que ele, da primeira à última linha, se trata no masculino e se dá um nome distinto daquele, feminino, que recebeu ao nascer. Não será isso uma forma de se pensar identidades trans? O termo que ele usa é "homossexual", termo que mesmo hoje em dia ainda vemos utilizado por muitas pessoas trans para pensar a própria condição (sobretudo as mais distanciadas do movimento LGBTQIA+) e que remonta a uma época em que, segundo a historiadora da transgeneridade Susan Stryker, não fazia sentido (ou não era possível) estabelecer uma diferenciação entre o que era do âmbito da orientação sexual e da identidade de gênero. Por mais que, muitas vezes, insistamos 
na distinção entre as duas esferas, é bastante nítido que algumas pessoas ainda hoje as borram de maneira irresolvível, motivo que me levou a não pestanejar em trazer para a lista autoras como Madame Satã e Vera Verão.

Revista Crioula: A literatura trans seria uma categoria estética ou política?

Amara Moira: Há um desejo de trazer luzes para essa produção. Produção que, como se vê, é enorme apesar de tão desconhecida. A etiqueta cumpre então com o papel de atiçar curiosidades e de propor uma organização da história dessas publicações.

Revista Crioula: O que acha sobre boa parte da produção literária trans brasileira ser autobiográfica? O que o gênero autobiográfico teria a ver com a transgeneridade?

Amara Moira: O cunho memorialista é, sim, nítido nesse levantamento, o que, com certeza, tem relação com o fato de a autoria ser de figuras pertencentes a um grupo extremamente estigmatizado. Nesse sentido, é como se elas quisessem que essas narrativas, chegando aonde seus corpos ainda não conseguiam, fossem preparando a sociedade para, de um lado, aproximar-se das subjetividades trans e, de outro, não se sentir mais tão ameaçada diante delas. A violência que dirigem a nós tem nitidamente origem na narrativa única que conceberam a respeito do que somos, do que representamos, como se pode perceber na pichação que Fernanda Farias de Albuquerque relata em Princesa (1994), feita na década de 1980, numa área de prostituição de travestis da capital paulista: "Limpe São Paulo, mate um travesti por noite". Se puderem nos ver por outras perspectivas, teremos mais condições de assegurar nossa existência... eis uma razão forte para ainda hoje insistirmos no teor memorialista. Outra razão tem que ver com o que esperam de nós, o que nos consideram capazes de conceber, o que se permitiriam publicar de nossa lavra, a resposta sendo óbvia, histórias sobre nossas vidas. No entanto, vejo que quanto mais vamos assegurando nossos espaços, mais vamos lançando voo em direção a outras experimentações, agora já não tão nitidamente autobiográficas (o exemplo mais acabado dessa nova leva é, sem sombra de dúvidas, o seu Sexo dos tubarões [2017], Naná).

Revista Crioula: Fale um pouco sobre a localização de personagens trans na literatura brasileira. Como lidar com o problema de nomear "trans", que é uma categoria atual, personagens ou pessoas que não possuíam esse conceito em seus contextos/épocas? 
Amara Moira: Por mais que não existissem personagens "trans" antes desse conceito, é certo que o surgimento desse conceito foi precedido por figuras que, na literatura e na vida, questionaram os limites rígidos e estreitos do que as palavras "homem" e "mulher", mas também "masculino" e "feminino", significavam. Não se pode compreender hoje o debate trans sem indagar sobre um passado de disputas em torno das noções de gênero que propiciou a enunciação dessas novas subjetividades. Investigar o comportamento da literatura, tanto a canônica quanto a marginalizada, diante dessas figuras questionadoras é uma forma de entender como fomos nos tornando o que nos tornamos e, como não há literatura que não reflita o debate de gênero feito em seu tempo, esse terreno é especialmente fértil para tais investigações. E não são poucas essas figuras, ao contrário do que poderia parecer, mas elas só se mostram para quem saiba reconhecê-las. É o que se passa com o Grande Sertão: Veredas (1956), de João Guimarães Rosa, romance que vem sendo ressignificado à medida que sujeitos como Diadorim se (a)firmam na sociedade e deixam de ser entendidos como "apenas um caso de identidade sexual equivocada". A legitimação cada vez mais visível das identidades trans nos permite a releitura de todo esse passado e, nesse esforço, se fazem cruciais as nossas sensibilidades e perspectivas, pois são reveladoras de dinâmicas que a sociedade ainda está aprendendo a identificar.

Revista Crioula: Fale um pouco sobre a relação entre literatura nacional e literatura trans, dado que a academia pensa muito a literatura a partir do viés do nacionalismo. A literatura trans poderia ser pensada no escopo de uma nacionalidade ou ela transcenderia essas fronteiras também?

Amara Moira: A pauta trans foi, a partir da década de 1950, em boa medida, sequestrada pela medicina, a grande responsável pela diferenciação irresponsável (e, no entanto, ainda hoje em vigor em muitos espaços, mesmo da militância) entre "travestis" e "transexuais". Essa diferenciação teve como principal propósito conceder legibilidade ao gênero da segunda categoria, propondo que pessoas transexuais deveriam ter seu gênero reconhecido por desejarem possuir o genital que se espera em homens e mulheres tidos como "legítimos". Esse raciocínio, no entanto, além de extremamente cis sexista, por querer que o genital (com que se nasce ou, agora, o que se deseja ter) defina o gênero de uma pessoa, ainda serviu para aumentar o estigma que pesava sobre a outra entendida como oposta, de travestis. Outro efeito nefasto dessa diferenciação é conceber a transgeneridade sobretudo em função da disforia, isto é, do sentimento de desconforto com as marcações de gênero percebidas em nossos corpos, e defender que a cirurgia é o melhor método para solucionar ou mitigar esse problema (nas palavras do sexólogo pioneiríssimo Harry Benjamin: “O travesti geralmente quer que o deixem em paz. Ele não demanda nada da categoria médica, a menos que queira um psiquiatra para tentar

Revista Crioula - n 24 - Dissidências de Gênero e Sexualidade nas Literaturas de Língua Portuguesa 
curá-lo. O transexual, no entanto, põe toda a sua fé e futuro nas mãos do médico, especialmente do cirurgião" [The transsexual phenomenon, 1966]). Algumas das nossas primeiras publicações trans surgem na esteira desse debate (como a de João W. Nery, Erro de pessoa: Joana ou João? [1984], ou a de Loris Ádreon, Meu corpo, minha prisão - Autobiografia de um transexual [1985]), mas há outras que só o conheceram indiretamente e que, portanto, nos permitem vislumbrar um sentimento transgênero que se forjou por aqui menos refém dessa diferenciação (como em Princesa) ou mesmo alheio a ela (como em A queda para o alto). Cumpre dizer, também, que esse levantamento que tenho realizado, com suas mais de setenta obras, coloca o Brasil num posto de destaque no quesito publicações trans.

Revista Crioula: Quais livros trans mais te impactaram e por quê?

Amara Moira: Dos estrangeiros, acredito que Transgender History (2008), de Susan Stryker, e Testo Junkie (2008), de Paul B. Preciado, por oferecerem maneiras intrigantes de repensarmos a história dessas identidades e ensinarem maneiras de conectarmos essa história com os grandes debates do nosso tempo. Dos brasileiros, com certeza os inesperados e já citados A queda para o alto e Princesa, mas também Viagem Solitária - Memórias de um transexual trinta anos depois (2011, reedição expandida do Erro de Pessoa de João W. Nery e primeira publicação trans de que tive notícia, anos antes da minha transição) e Liberdade ainda que profana (1998), de Ruddy Pinho, quatro obras autobiográficas que nos ajudam a reconstruir a maneira como as transgeneridades foram se forjando no Brasil. E também o livro de Naná, que me desafia a imaginar os próximos passos dessa produção trans, rumo a experimentações cada vez mais ficcionais. 